\title{
Writing at the Centre: Language, Institution, and the Discourse on Writing Centres
}

\author{
Janet Giltrow \\ Simon Fraser University
}

Preparing to speak about writing centres to an audience of writing specialists, I drafted an account of what might be called, at an abstract level, "the politics of service": the situation of writing-centre work amidst the academic disciplines. At a more concrete level my draft was about the Centre for Research in Academic Writing at Simon Fraser University - how we got started, what people say about the writing centre, how our colleagues in other disciplines react to our research findings, how we feel about what we do.

Having got my feet on the ground with this draft, I began to take into consideration other views of writing centres. Reading the published record, I experienced many moments of recognition: these writers also told how they got started, what others said about the writing centre, how their colleagues reacted, how they themselves felt about their work.... And, despite the variety of circumstances and concerns these publications addressed, they were united in certain distinguishing features: narrative passages with the writer as agent of action, object of reaction, or experiencer of conflicting sensations; numbers - of students, staff, hours, computers — ; anecdotes of telling cases.

$M \gamma$ reading deflected my original intentions. Rather than produce another entry for the annals of the Writing Centre in North America, I began to reflect on the conditions which determined the form of publications which issue from writing centres. What institutional dispensations constrain or inspire this discourse? As I explain below, my research site is principally the discourse itself, and its quality as addressed to surrounding conditions 
and discourses, and its construction or representation of a certain institutional position. And, although I abandoned my first draft - narrative, numerical, anecdotal - I still speak from that institutional position, as a writing-centre worker. I share this position with the authors I cite below. Like them, I refer to some conditions I can document only as my own experience of the writing centre's contingency on its surroundings.

UNLIKE ENGLISI DEPARTMENTS OR COMPOSITION COURSES, writing centres are relatively recent features of the academic landscape. In a relatively short time - some say 30 years, more say 20 , and in Canada we should probably say ten years - writing centres have established themselves, become normal, and self-evident. ${ }^{1}$ How has this happened? How have writing centres become self-evident - even as workers in writing centres continue to define their activities for their institutions, for outsiders, and often for themselves? How has this not-quite-defined thing become standard?

One way of answering this question is to take an historical view, and look for origins. Some people have traced the writing centre to traditions of tutoring the children of the élite - traditions now democratized. One commentator finds a forefather in Socrates (North, 1984, p. 446). Some take a socio-historical view, and find that changes in U.S. university populations made conditions fertile for the seeding and growth of writing centres. As well as these long views, with historical panoramas, the account of the writing centre also contains many individual histories - how in, say, 1978 or 1983, at a large or small institution, somebody got an idea, or an English department took an initiative... All these originary - or epic - histories can be useful: they dignify the writing centre with an identity over time, and encourage solidarity.

I too will take an historical view, but one less concerned with origins. This view will picture the writing centre as historical in the sense of being contingent on surrounding conditions - dependent on these conditions, possible but not inevitable. Like the originary history, the contingent history is also useful. Perhaps it is an even more practical approach to examining the self-evidence of writing centres, for it locates them amidst other discourses

1. Recently, at a meeting of a provincial committee, representatives of post-secondary English departments in British Columbia were asked to answer this question: "Do you have a writing centre?" Almost everyone had a writing centre. Those who did not have a writing centre expressed their desire to have one, or their feeling that they should have one. Writing centres were the norm rather than the exception. 
and institutional formations, adjacent territories and contributing resources; a contingent history maps routes of exchange or trade, incursion or expropriation. Such an approach cannot predict exact moments of hazard or opportunity, but it may induce an alertness to pressures: a kind of seismic sensitivity.

In replying to my own question - "how did writing centres become self-evident?" - I attempt not a comprehensive history but a survey of saliences in a decade (1984-1994) of the discourse on writing centres. For every statement I cite, and every generality I offer, readers will be able to think of exceptions, and indeed both writing centres and their contexts are diverse. My generalities are estimates from my position - at a mid-size Canadian university whose English department has had a writing centre, in some form, for 15 years - and they are informed by theoretical principles that will become evident. The statements I cite are those which are salient from this perspective.

My sources are principally four important collections on writing centres $^{2}$ - 64 articles, and four introductions - and two of the several books about one-on-one tutoring. ${ }^{3}$ My sources are also principally American. This provides for an attitude of both estrangement and familiarity: U.S. circumstances are not ours, but I think readers will recognize them - and at the same time profit from the distancing.

\section{The trade in abstractions}

In this contingent history, I'll begin with one particularly prominent contingency. As supplementary or auxiliary to the established disciplines, writing centres have an attenuated connection to budgets. With greater or less urgency or regularity, writing centres must define themselves and their activities seasonally to get funding. Unlike established disciplines, they must elaborate themselves in reports and proposals. To engage the resources of

2. Gary A. Olson, ed. 1984 Writing Centers: Theory and Administration. Urbana: NCTE; Ray Wallace and Jeanne Simpson, eds. 1991 The Writing Center: New Directions. New York: Garland; Joyce A. Kinkead and Jeanette G. Harris, eds. 1993 Writing Centers in Context: Twelve Case Studies. Urbana: NCTE; Joan A. Mullin and Ray Wallace, eds. 1994 Intersections: Theory-Practice in the Writing Center. Urbana: NCTE.

3. Muriel Harris. 1986 Teaching One-to-One: The Writing Conference. Urbana: NCTE and Emily Meyer and Louise Z. Smith. 1987 The Practical Tutor. New York: Oxford. Both volumes collect and echo statements on one-on-one instruction which preceded them, and both continue to resound in citations in subsequent publications. 
the institution, writing centres produce statements which register audibly there - statements about "literacy," and about "communication skills," and, at a pinch, about "critical thinking."

These statements reproduce not only current themes in public education but also those of corporate interest and of millennial economic forecasts. Writing-centre definitions which invoke "communication skills" - directly or indirectly - can be exchanged with administrations for funding; administrations can in turn exchange these definitions with legislators, and with the private sector. If the writing centre can also gesture towards computer technology at the same time as it invokes literacy, it will amplify its statements; they will reach more points in the public discourse on employment and the future.

This seems like a tidy bargain: the writing centre produces statements which cooperate with other themes and practices, like the discourse on literacy or the excitement about technology. But there are risks in such cooperation. Joyce Kinkead (1993), for example, notes that computers in Utah State University's writing centre caused, "ironically," she says, "some unwanted attention from the university administration," which funded computers not only to "improve writing," but also to increase "what the state has termed 'productivity,' which translated as larger classes. Similarly, [the administration] also purchased Writer's Workbench because they visualized writing instruction without teachers" (p. 204). There can also be potential "ironies" in funding earned by statements on literacy and communication skills: the writing centre can find itself becoming a term in the problematizing of student writing. Not far away are tests, thresholds and placement devices - and other forms of "unwanted attention."

Reflecting on these "ironies," I think of Kenneth Burke's $(1966,1969)$ reminder that the higher the abstraction and the more embracing its constituency, the more likely it is to conceal actual difference and division of interest. The term "literacy" operates at a very high level of abstraction, "communication skills" at a higher level still, with an even more inclusive constituency - everybody loves literacy; everybody wants students to have communication skills. Kinkead offers one testament to the kind of division of interest that can be concealed by institutions' investment in "literacy."

But how did writing centres get their license for such high-level trade in abstractions? How do writing centres - upstart, reputedly marginal get the ear of the administration in the first place? What conditions have positioned writing centres to speak so profitably to frugal administrators? 
Delving into the terms of the writing centre's legitimacy, we will find that it is assigned many of the values traditionally inhering in established institutional entities and that it participates in longstanding ideologies of language. We will start this delving by investigating the writing centre's position vis-àvis the English department.

\section{The writing centre and the English department}

Many writing centres are, of course, organizationally independent of English departments, but the fact remains that writing centres have on-going relations with English Departments even when they are organizationally separate. The most durable ties in these relations are not the overt, organizational ones, but the covert ones, intricate, self-replicating, and difficult to confront - and more powerful for their covertness. In trying to expose these links, I will first provide evidence that, no matter how determined writing centres are in their efforts to define themselves (and, in a sense, an organizationally discrete position can be an attempt at selfdefinition), they are still objects of interpretation by their neighbours. Writing-centre faculty can find neighbourly interpretations provoking. In the published account, there are many claims about the need to change attitudes, and many reports of the writing centre being seen as a troubleshooter, a last resort for problem writers. Here is one:

... I wince when I hear about how some ... faculty describe the writing center to their classes (albeit with good intentions) or when I read some of the descriptions of the writing center that appear on paper assignments ("If you are having trouble writing English, go to the writing center"). (Hughes, 1991, pp. 41-42)

Where do these attitudes come from? Writing centres are locally defined by materials that have accumulated over many generations, and one of the earliest and most insistent complaints about bad attitudes (North, 1984) traces these materials to English departments themselves. Here a later report makes a similar attribution, representing an English department as quick to rank speakers and to categorize certain users of English as "not [belonging]":

[English department faculty begin] to see the lab as yet another remedial crutch for those "who do not belong in school to begin with." ... if the department faculty feel this way about the lab, the overall faculty from 
across the disciplines may soon catch this disease. (Wallace, 1991,p. 84)

At first glance, these views might suggest that the typical English (literature) department rejects the writing centre as a body might reject a transplanted organ. But other evidence suggests that writing centres under certain conditions of definition, especially as "remedial" - are in fact at home in English departments. After all, handbooks - instruments of correction and normalization, product and tool of the composition industry - are capital goods of English departments, especially those devoted to the priority of literary study.

To understand - or, at least, to observe - this cooperation between the traditions of literary study and those of writing instruction, we can turn to several theorists who have inspected these complicated connections. Susan Miller (1991) has vigorously rendered the relation of literary studies to composition, describing an historical, enduring, and carnivalesque affinity: composition is "the travelling sideshow stationed beside the 'great' texts" (p. 36) of literature; composition is a "carnival...simultaneously regulated and disowned" (p. 81) by the authority of literary study. Others have revealed further aspects of the attitude which conflates knowledge of literature and knowledge about language, and the capacity of this attitude to relegate low-ranked spejakers to systems of correction. Tony Crowley (1989) shows the historical derivation of "standards" from the practice of literary study and the contemporary contribution of the literary professorate to talk of standards; Pierre Bourdieu's analysis of language $(1977,1991)$ describes the role of the speech habits and privileges of professors in generating the "symbolic power" of language, its capacity to dominate and stratify speakers; and Bakhtin (1981) exposes the "sealed-off caste" (p. 368), the "privileged community" (p. 382) that produces "a privileged category of value, 'the literariness of language,' or (...) 'making language respectable" (p. 381). According to Bakhtin, these operations are conducted by certain "forces" - “an academic grammar, a school, salons, literary tendencies, specific genres and so forth" (p. 382) - which we in turn can readily associate with the literary-critical profession. All these conditions assign to English departments guardianship of the language, a role they rarely reject and one that neighbouring departments and larger administrative structures are quick to presuppose as part of the natural habits of English departments. And whatever their nominal situation - stand-alone, or part of an English department - writing centres are liable to be associated with 
this guardian role and its discriminating practices, its vigilance as a corrective regulator in the life of the language, its capacity for remediation.

\section{Guardians of English and unitary views of language}

Writing centres' involvement in guardianship is not confined to this problem of attitudes - the problem of getting others to change their ideas of writing-centre work. The conflation of knowledge of literature and knowledge of language has further implications for the writing centre's position, implications which bear on both the administrative profile of the writing centre, and its own role in constructing knowledge of language. Crowley, Bourdieu, and Bakhtin all insist on the link between the "literary" derivations of habits of linguistic invigilation and unitary views of language - or, as Bourdieu says, the "unification" of the linguistic marketplace (1991, pp. 47-48). According to Milroy and Milroy (1985, 1991), important contributors to the analysis of authority in linguistic matters, those who participate in the "complaint tradition" - activists in the campaign for unification typically insist on one correct form where practical variants exist (pp. 40, 52, 76). Insensitive to context and denying variety, the unitary view proposes an ideal. In the unitary view, the language of a particular class, supported by handbook fastidiousness, is naturalized.

The unitary view produces statements about language that speak to other discourses - not only ideologies of class and race but also ideologies of management. The unitary view of language operates in the conceptualization of the writing center as "remedial," for it provides many instruments for the detection of error, and deviance from norms: testing, screening, standards, placement, monitoring of progress, surveillance of populations. And the unitary view - deeply secured by the conflation of literary and language studies — is efficient to managerial purposes not only in administering student populations but also in administering personnel. As long as the administrative unconscious links literature departments and language, the staffing/funding discussion is open to a range of possibilities - from tenured full-time to non-tenured full-time to part-time to sparetime (literature faculty can just do this work as a matter of habit) to no-time (as in the undergraduate-peer-tutor option - writing-centre consultation is made from the atmospheric materials of English departments). ${ }^{4}$

4. Note that this range of possibilities would never be entertained in discussion of, say, finding someone to teach Victorian fiction or eighteenth-century literature. 
For most (but not all) writing centres, the "spare-time" option has been defeated. But the grounds for it survive: while spare-time has been cancelled as a legitimate statement in institutions where the writing centre has taken hold, the assumptions which enabled it in the first place still operate. Where funding is a seasonal affair, staffing remains a site for definition - who will meet students in the writing centre? how will they be paid? - and an occasion for the production of statements which activate unitary views of language and the traditions which assign literature departments and "English" custody of the language.

For the most part, writing centres don't want to be seen as "remedial." But they are institutionally destined to be complicit in the system of claims and assumptions which produces this perception: without the general sense of students' language being problematic, or deviant, writing centres might find their raison-d'être much harder to argue. Moreover, their own published accounts, in which writing centres speak to each other, also invoke universalizing assumptions about language - the very assumptions that produce the "standards" that make "remedial" action possible.

\section{Writing centres and the reinvention of unitary views}

Back in 1984, when Kenneth Bruffee published one of his often-cited accounts of "conversation" and writing, stabilizing the micro-discourse of the writing centre as "talk," he referred to "expository writing" — a unitary term derived from the traditions of "composition." At the same time, Cobb and Elledge (1984) discussed peer-tutoring: how can you tell you need peertutoring? Survey faculty (a sure way to get expressions of unitary views of language which valorize correctness and deplore declining standards); check "final grades" in freshman English (another way to get unitary views, but expressed in a different form). These ideas operated over a decade ago. Since then Writing Across the Curriculum has helped to diversify the profession's unitary notions about writing, and, as many note, WAC and writing centres are closely related. Early gestures from writing centres towards WAC seem not to disturb founding principles: Meyer and Smith's (1987) chapter on writing "across the disciplines," for example, confines itself to problems with quotation and "vocabulary." But what statements appear in the writingcentre discourse in the 1990s? In 1991, Karyn Hollis writes about training tutors to "lead group tutorials on biology lab reports," urging that writing centres colonize this remote territory: "If, as we believe in theory, everyone benefits from instruction in the writing process, our science students are 
probably deprived" (p. 247, emphasis added). ${ }^{5}$ In the same volume, William Wolff reports on adapting heuristic guidelines to the needs of writers in other disciplines - education, business and economics, health-care administration, psychology - and his samples show how these guidelines become differentiated. But composition values still infiltrate them and reduce their differentiation: no matter what their situation, readers and writers value "logic," "complete" and unified paragraphs, prefer the active voice, disprefer sentence-initial "it," "this," and "there."

By the early 1990s, the discourse on difference has touched the writing-centre discourse. Christina Murphy (1991) writes a strong analysis of the writing centre as simultaneously accommodating "conservative," "liberal," and "radical" motivations, and Gail Okawa (1993) speaks compellingly from the margins - the Educational Opportunity Program Writing Center at the University of Washington, where non-traditional students negotiate conflict and compromise with the notoriously unitary disposition of freshman composition at the university. But, on the whole, the writing centre discourse is a modestly transformed version of the "composition" discourse, which has done long service for English departments and unitary views. In 1993 Linda Simon writes that "[p]otential tutors... need to believe, even before they are hired and trained, that good writing transcends any particular discipline and that the concerns one has about writing are not discipline-specific or paper-specific" (pp. 121-22). Simon repeatedly refers to the "thesis statement" as a specialty of the writing centre: students can be "[timid] in stating a thesis" (p. 115); students who are "less able" are those "who have not mastered the formulation of a strong thesis statement" (p. 118). With such clients, the "thesis" can be the focus of a conference (p. 125). Others, too, claim the making of a thesis statement as an area of expertise (e.g., Addison \& Wilson, 1991; Clark, 1993), along with work on "organization." All these are gestures towards a unitary notion of writing: good writing is directed -in process and product — by a thesis statement. So, in 1994, even as Muriel Harris writes on "[individualizing]" instruction to respond to "cross-cultural difference," and introduces some relativity to the discussion, she focusses on the presence or absence or profile of the "thesis statement" in writing from different cultures.

5. This view predates Paré and Smart's (1994) and others' reasoning about different genres activating different writing processes - but even if this work had been available at the time, it might not have registered, for the formations of writing-centre discourse have been able to accommodate only limited ideas of genre. 
At the same time, in the early and mid 1990s, and despite disclaimers, writing-centre discourse still invoked the writing process - something explained and taught. Even "non-traditional" students can be met with normalizing routines. Ellen Mohr (1993) reports that, for the "returning adult" - "frequently a middle-aged female" - writing centre tutors "review the basics, explain the writing process, and offer...the opportunity to write in a variety of rhetorical modes" (pp. 151-52). Difference is briefly entertained by "rhetorical modes" (as Miller, (1991) observes, a strategic simplification of the actual diversity of real-world writing), but difference is much more decidedly located in the individual writer - who, in writingcentre practice, gets separate instruction, and may find her interaction with her tutor differentiated psychologically, by taxonomies of personality type (e.g., Scharton \& Neuleib, 1991; MacLennan, 1994). Difference in a social or political sense is reduced to the concept of "audience": a notion alienated from genre or function or precedent, and brought into being in the writing centre through "audience analysis" (e.g., Keene, 1991; Clark, 1993). ${ }^{6}$

The writing centre has not been hostile to interests that have long profited from the unitary view of language embedded in English departments. Writingcentre discourse has been contingent on the discourse on standards and deviance and many statements issuing from writing-centre positions from the early 1980 s to the mid 1990 s continue to mention "diagnosis" (e.g., Olson, 1984; Croft, 1984; Simard, 1984; Meyer \& Smith, 1987; Clark, 1988; Harris, $1986,1993)$, reminding us of the early designation as "clinic" or "lab," and of the immanence of testing and placement. But if the writing centre only replicates existing ideas and practices, how does it emerge as a distinct entity? Why is it there if it only duplicates what already exists?

\section{Record-keeping}

One activity which distinguishes the writing centre is its documentary practice. Writing centres keep records. Smith (1984) devotes an early discussion to managing the "flow of paper" that goes towards constituting a writing centre. Cobb and Elledge (1984) offer advice on pre- and posttests and grades that measure the effect of writing-centre visits; they also include a sample evaluation form which asks students about tutors' performance - focussing on tutors' friendliness, accessibility, understanding.

6. Meyer and Smith's The Practical Tutor (1987) devotes only a few paragraphs to "audience," advising the tutor to question the student on the reader's knowledge of and interest in the topic or "problem" (80). 
These are examples from 1984, but by the early 1990s, writing-centre workers are still occupied with the arbitrage of records: Simpson (1991) recommends record-keeping to demonstrate the connection between writing-centre visits and "retention" - another record-keeping system for administering populations of students and faculty. And as writing centres approach the mid 1990s they are still typically concerned with recording every use of the writing centre, this record often involving dossiers and reports to students' classroom teachers. An exemplary "Writing Center Tutor Report" (Mullin \& Momenee, 1993) relocates and revives the formalities of the traditional handbook: after checking the writer's "stage" in "the writing process," the tutor records the writer's need for "assistance with content" (including "thesis," "logic," use of "examples," "appropriate tone and diction"); need for assistance with "organization or format" (including "introduction, body and conclusion;" assistance with "grammar or mechanics" (pp. 66-67). As Kinkead says, "Although keeping records sometimes seems to exist on the same level as error-hunting, we know that records keep the center in operation" (1993, p. 207).

Records verify the writing centre. From an auditor's point of view, the records are the writing centre. Shifting instruction from the macro-level of classrooms, courses, fees, and credit hours to a micro-level, the writing centre devises new systems of at once configuring aggregates and tracking individuals. Without these sums and traces, there will be no route or destination for institutional funds.

The records which reply to the institutional audit can be converted to leave another kind of trace on the institutional surface. After listing presentations and publications arising from his writing centre's work, Edward Lotto (1993) writes:

All this work demonstrates the wealth of knowledge generated in a writing center if we are careful enough to keep track of what is going on. Writing centers are where much of the writing process comes out in the open, and we need to analyze this information both practically and theoretically for the sake of both writing centers themselves and our understanding of composition in general. (pp. 94 - 95)

Record-keeping blends into research — an accumulation that registers in other institutional ledgers. Neuleib \& Scharton (1994) are even more explicit on this point, seemingly arguing that techniques of managerial 
record-keeping are research by another name:

In keeping records, writing centers have written a critical history of the contact between students and the professorate. We have been taking notes on our center for years, not so much to understand it as to answer the feared attacks of budget cutters who someday might strike. These data provide one version of fieldnotes: notes that cover everything from tutor activities to the content of grammar hotline calls, students papers both in tutoring files and in writing assessment folders, recorded interviews with tutors, evaluation forms filled out by tutors and the students with whom they worked, and our own massive year-end reports based on a data-keeping system comparable only to the federal government's spy system back in the cold war days. These records are the key to beginning an ethnographic study.... (p. 57)

\section{The writing centre and its knowledge base}

Even in light of these rich accumulations, we still might ask what is the body of knowledge used and produced by the writing centre? An early answer comes from Hawkins (1984): "Writing centers have concentrated on student learning rather than on a 'subject' of study" (xiv). Other early examples suggest that the writing centre's knowledge base is - not surprisingly - continuous with the knowledge base of composition, which in turn has historical affinities with the disciplinary perspectives that assign the guardianship of the language to literature departments. But maybe this should be surprising in that trends towards Writing Across the Curriculum disturb the assumptions which conflate literary and language studies, and writing centres' institutional position (flexible, in-between, open to all) has made them a site from which Writing Across the Curriculum initiatives originate. It seems, though, that the unitary view of writing - adapted, rotated a few degrees - has a prior claim. Even in the mid 1990s, writing centres are still occupied with the rhetorical context of the composition classroom - and the production of text in what Bourdieu calls the "semi-artificial language sustained by constant correction" (p. 60). Harris (1993, pp. 12-16) provides a transcript of a tutor's consultation with a student who is writing an "argument" about campus parking; the tutor's response moves from "narrowing the topic" to "examples" - well-known prompts or procedures for producing the genre called for by the all-purpose composition course. Even 
theoretically sophisticated commentaries find their examples in student essays about capital punishment (Gillam, 1994), or the writer's grandmother (Jacoby, 1994), or topics writers have to jump-start all by themselves (as in the case of the writer who eventually finds himself in an essay on logos on football helmets [MacLennan, 1994]). ${ }^{7}$

At the same time, writing centres have entertained challenges to the unitary view. In an early instance of thinking about what to do about business and technical students, Fearing \& Sparrow (1984) summon the stereotypes of business writing - that business people are too busy to read and that the rule is "absolute clarity"” (p. 216), and that, "[i]ndoctrinated as they are by their disciplines, business and technical students often err in selecting the impressive over the expressive word" (p. 216). Specialists in clarity $^{\mathbb{8}}$ and expressiveness, writing-centre faculty absorb and subdue difference (even accommodating limited use of the passive voice [pp. 219-20] while maintaining an overall disapproval of it). They are also in a position to judge the documents which function in other disciplines:

abstract words abound in poorly written business and technical documents, and since students tend to imitate what they read, they assiduously plant abstractions in their writing. (p. 217)

Like many handbook authors and computer style-checkers, Meyer \& Smith (1987, p. 298) warn about nominalization, and even when the writing centre is more attentive to difference, as in the case Wolff (1991) offers, where writers' guidelines were adapted to diverse disciplines, the values of composition insinuate themselves.

As we reach and overtake Wolff, we may measure some movement. But the force of surrounding habits and expectations tends to stall this movement. Recently, giving a talk about writing centres to an institution hoping to get one, I showed some samples of the acute stylistic differentiation of

7. As Miller (1991) points out, writers relegated to freshman composition are typically assigned topics which expose their personal lives.

8. Deborah Cameron (1995) notes that authorities on "good writing" habitually invoke "a set of global stylistic maxims...: injunctions to be clear, precise, definite, simple and brief, while avoiding obscurity, ambiguity, vagueness, abstraction, complication,jargon and cliché.... authorities typically present clarity et al. as if they belonged to some pure and timeless realm of self-evidently desirable qualities. In fact these norms are neither universal nor neutral. They have a history and a politics" (64). 
disciplines. Among my samples was an opening paragraph from an article in a journal of management studies: this paragraph did indeed "abound" in abstractions - the kind produced by the nominalization of transitive verbs. A member of the audience, a literature and composition teacher of many years experience, said, "You mean we're supposed to teach students to write that way?" This was an important question, one which voiced enduring values that continue to situate writing instruction in the institution. The question called up, even in 1996, and even in a discussion of an innovation for this English department, abiding beliefs about good writing, ideals of clarity, voice, thesis statements, paragraphs and their unity.

\section{"Process" and talk in the writing centre}

But, as writing centre advocates have said all along, or at least since the early $1980 \mathrm{~s}$, their focus is on process, not product. (Olson stated emphatically in 1984 that the writing centre's business is drafts, not marked papers, and most commentators have gone ahead on this assumption. Harris (1986), for example, says that "any seasoned conference teacher will immediately (and vehemently) concur" with the view that the "only stage" of the writing process not appropriate for one-on-one consultation is "after a final draft" (p. 50). Since process is a less observable condition than product, writingcentre practice develops to render process visible. ${ }^{9}$ Talk brings out process, and, as many note, talk is the core of the writing centre's performance. Writingcentre workers are trained to converse expertly with students to coax out their intentions and assumptions, to identify their "stage" in the writing process, to guide them towards that process if they haven't found the route. Expert talk manages affect - diffidence, hostility, reluctance, anxiety. Expert talk - delicate but tireless questioning - compensates for the relative poverty of writing-centre discourse on text — limited to somewhat formalist notions like "thesis," "organization," and paragraphs, and legitimized by insisting that the focus is "higher order" (e.g., Harris 1986, p. 32). By conversing expertly, writing-centre workers establish points at which to intervene. This talk gathers its own momentum, flowing over the boundaries of the writing-centre consultation into the journals many peer

9. We might observe parallels between the ascendancy of the writing centre and the enthusiasm for computer-aided instruction in writing. It has been argued (Giltrow, 1989) that the welcome computers received in the 1980 s in some composition programmes is attributable to their capacity for enabling instructors to intervene more penetratingly than ever in students' "composing process." 
tutors are required to keep, and into publications. Some of these publications are devoted to memoirs of the experience of contact and intervention. Others, not exclusively devoted to such disclosure, nevertheless turn to anecdotes of writing-centre conversation. Practice becomes record, and record forms the knowledge base of the writing centre.

How is it that writing centres - in many ways a striking departure from usual forms of instruction - have become self-evident so quickly? I have suggested that writing-centre discourse enters into profitable exchange with the larger discourse on literacy, information, and millennial economic forecasts. These profits may come to be heavily taxed when the actual differences in interest - concealed by high-level abstractions like "communication skills" - come to light. The perennial sound of complaint about people having the wrong idea of writing centres is evidence of this difference in interest.

Yet even as the writing centre feels misunderstood, its own practice, its process attitude, perpetuates its contingency on enduring, heavily subscribed ideas about language. English departments have long had custody of these ideas-notions about correctness and standards, but most important the idea that students' language can be worked on. Once "process" methods are added to this idea, the capacity for working on writing expands to working on writers, and English departments, perhaps in spite of themselves, earn bigger reputations than ever for operating on the speech of populations. This zone of concepts and activities is patrolled by unitary ideals. (So North (1984) says that "in a writing center the object is to make sure writers, and not necessarily their texts, are what get changed by instruction" (p. 438) and, at the same time, approves of the instructional goal of "[developing] general patterns of thinking and writing" (p. 435, emphasis added).) Unitary ideals often conflict with the actualities that Writing Across the Curriculum brings out of the woodwork - but they nevertheless seem to survive the conflict.

This analysis suggests that writing centres do not rupture or rend the institutional fabric but, rather, elaborate it. But why have writing centres not only appeared but also flourished - grown and prospered even in times of public frugality? This prosperity may be attributable to their routines of record-keeping. Writing centres are a departure from usual instructional forms, and the attenuated position that keeps them at arm's length from established disciplines has also obliged them to continually report their existence, define and project themselves, consult and publish their records. 
Record-keeping ascends to statistical aggregates which trace populations, and descends to individual detail which records not only the student type ("stage" in the writing process, characteristic deficiency, and so on) but also the configuration of "talk" itself. So the tutor's training becomes part of this legible record - the tutor is deeply informed as to how to question, how to get the student on record, how to report that talk, and how to record reflection on the report. (Such reflexivity is a prominent theme of recent publication.) Because of its special institutional position, interstitial, seasonally verified by more talk and writing, the writing centre is a high-density screen for the representation and practice of technique. As Foucault (1991) says, finalities of "governmentality" and liberal society are the intensification and perfection of technique - these finalities often requiring that administrative activity be delegated, as Donzelot observes (L'invention du social, cited in Gordon, 1991, p. 25).

Writing centres are a catchment for surpluses in the institutional population: catchment for what can't be administered in the classroom or on transcripts or in hard-money budgets. We could take a sceptical view of this function, but we could also take a positive view. Many commentators remark on the subversive aspects of life in the writing centre - from the Warnocks' (1984) early claim that the writing centre is "liberatory" because of its marginal position to later claims that writing-centre practice challenges the institution (Lassner, 1994) or that it can incite critical literacy which evaluates rather than simply adopts literate practice (Mullin, 1994). ${ }^{10}$ The writing centre's interstitial position makes it a place where standard assumptions about language can be reproduced and traded: as populations come and go, and as it negotiates its own definition, the writing centre traffics in prevailing and normative ideas about speakers and their language. But this position also makes the writing centre a hermeneutical junction ${ }^{11}$ from which the institution can be interpreted.

10. Mary Mar (1996), writing in Inkshed, says that the writing centre provides for "genuine communication," distinct from "the academic game."

11. See Mary Abscal-Hildebrand (1994) on applying concepts from Gadamer to writing-centre practice. 


\section{References}

Abscal-Hildebrand, M. (1994). Tutor and student relations: Applying Gadamer's notions of translation. In J. A. Mullin \& R. Wallace.(Eds.), Intersections: Theory-practice in the writing center. Urbana: NCTE.

Addison, J., \& Wilson, H. (1991). From writing lab to writing center: Reinventing, advancing, and expanding. In R.Wallace \& J. Simpson. (Eds.), The writing center: New directions. New York: Garland.

Bakhtin, M. M. (1981). The dialogic imagination (C. Emerson \& M. Holquist, Trans.). Austin: University of Texas Press.

Bourdieu, P. (1991). Language and symbolic power (G. Raymond \& M. Adamson, Trans.) Cambridge, Mass.: Harvard University Press.

Bourdieu, P. \& Passeron, J.-C. (1990). Reproduction in education, society and culture (R. Nice, Trans.) London: Sage. (Original work published 1977).

Bruffee, K. A. (1984). Peer tutoring and the 'conversation of mankind.' In G. A.Olson. (Ed.), Writing centers: Theory and administration. Urbana: NCTE.

Burke, K. (1969). A rhetoric of motives. Berkeley: University of California Press. . (1966). Language as symbolic action. Berkeley: University of California Press.

Cameron, D. (1995). Verbal hygiene. London: Routledge.

Clark, I. L. (1993). The writing center at the University of Southern California: Couches, carrels, computers, and conversation. In J. A. Kinkead \& J. G. Harris (Eds.), Writing centers in context: Twelve case studies. Urbana: NCTE.

. (1988). Preparing future composition teachers in the writing center. College Composition and Communications, 39(3), 347-350.

Cobb, L. \& Elledge, E. K. (1984). Undergraduate staffing in the writing center. In G. A. Olson (Ed.), Writing centers: Theory and administration. Urbana: NCTE.

Croft, M. K. (1984). 'Would prefer not to': A consideration of the reluctant student. In G. A. Olson. (Ed.), Writing centers: Theory and administration. Urbana: NCTE. 
Crowley, T. (1989). Standard English and the politics of language. Urbana: University of Illinois Press.

Fearing, B. E., \& Sparrow,W. K. (1984). Tutoring business and technical writing students in the writing center. In G. A. Olson. (Ed.), Writing centers: Theory and administration. Urbana: NCTE.

Foucault, M. (1991). Governmentality. In G. Burchell \& C. Gordon (Eds.), The Foucault effect: Studies in govermmentality, Burchell and Colin Chicago: University of Chicago Press.

Gillam, A. M. (1994). Collaborative learning theory and peer tutoring practice. In J. A. Mullin \& R.Wallace (Eds.), Intersections: Theory-practice in the writing cCenter. Urbana: NCTE.

Giltrow, J. (1989). Computers in composition: Inscribing new facts, Configuring new knowledge. Technostyle, 8(3), 1-15.

Gordon, C. (1991). Governmental rationality: An introduction. In G. Burchell \& C. Gordon (Eds.), The Foucault effect: Studies in governmentality. Chicago: University of Chicago Press.

Harris, M. (1994). Individualizing instruction in writing centers: Attending to cross-cultural differences. In J. A. Mullin \& R.Wallace (Eds.), Intersections: Theory-practice in the writing center. Urbana: NCTE. (1993). A multiservice writing lab in a multiversity: The Purdue University writing lab. In J. A. Kinkead \& J.G. Harris (Eds.), Writing centers in context:Twelve case studies. Urbana: NCTE.

(1986). Teaching one-to-one: The writing conference. Urbana: NCTE.

Hawkins, T. (1984). Introduction. In G. A. Olson.(Ed.), Writing centers: Theory and administration. Urbana: NCTE.

Hughes, B. T. (1991). Writing center outreach: Sharing knowledge and influencing attitudes about writing. In R. Wallace \& J. Simpson. (Eds.), The writing center: New directions. New York: Garland.

Hollis, K. (1991). More science in the writing center: training tutors to lead group tutorials on biology lab reports. In R. Wallace \& J. Simpson (Eds.), The writing center: New directions. New York: Garland. 
Jacoby, J. (1994). 'The use of force': Medical ethics and center practice. In J. A. Mullin \& R. Wallace (Eds.), Intersections: Theory-practice in the writing center. Urbana: NCTE.

Keene, N. A. (1991). Portfolio evaluation: Implications for writing centers. In R.Wallace \& J. Simpson (Eds.), The writing center: New directions. New York: Garland.

Kinkead, J. A. (1993). The land-grant context: Utah State University's writing center. In J. A. Kinkead \& J. G. Harris (Eds.), Writing centers in context: Twelve case studies. Urbana: NCTE.

Kinkead, J. A. \& Harris, J. G. (Eds.). (1993). Writing centers in context: Twelve case studies. Urbana: NCTE.

Lassner, P. (1994). The politics of otherness: negotiating distance and difference. In J. A. Mullin \& R. Wallace (Eds.), Intersection: Theory-practice in the writing center. Urbana: NCTE.

Lotto, E. (1993). The Lehigh University writing center: Creating a community of writers. In J. A. Kinkead \& J. G. Harris (Eds.), Writing centers in context: Twelve case studies Urbana: NCTE.

MacLennan, T. (1994). Buberian currents in the collaborative center. In J. A. Mullin \& R. Wallace (Eds.), Intersection: Theory-practice in the writing center. Urbana: NCTE..

Mar, M. (1996). The community and the discourse of a writing centre. Inkshed, 14(3), 4-6.

Meyer, E. \& Smith, L. Z. (1987). The practical tutor. New York: Oxford University Press.

Miller, S. (1991). Textual carmivals: The politics of composition. Carbondale: Southern Illinois University Press.

Milroy, J. \& Milroy, L. (1991). Authority in language: Investigating language prescription and standardization (2nd ed.). London: Routledge.

Mohr, E. (1993). Establishing a writing center for the community: Johnson County Community College. In J. A. Kinkead \& J. G. Harris (Eds.), Writing centers in context: Twelve case studies. Urbana: NCTE. 
Mullin, J. A. (1994). Literacy and the technology of writing: Examining assumptions, changing practices. In J. A. Mullin \& R. Wallace (Eds.), Intersections: Theory-practice in the writing center Urbana: NCTE.

Mullin, Joan A., \& Momenee, L. (1993). The writing centers at the University of Toledo: An experiment in collaboration. In J. A. Kinkead \& J. G. Harris (Eds.), Writing centers in context: Twelve case studies. Urbana: NCTE.

Mullin, J. A. \& Wallace, R. (Eds.). (1994). Intersections: Theory-practice in the writing center. Urbana: NCTE.

Murphy, C. (1991). Writing centers in context: responding to current educational theory. In R.Wallace \& J. Simpson (Eds.), The writing center: New directions. New York: Garland.

North, S. (1984). The idea of a writing center. College English, 46(5), 433 446.

Neuleib, J. W. \& Scharton, M. A. (1994). Writing others, writing ourselves: Ethnography and the writing center. In J. A. Mullin \& R. Wallace (Eds.), Intersections: Theory-practice in the writing center. Urbana: NCTE.

Okawa, G. Y. (1993). Redefining authority: Multicultural students and tutors at the Educational Opportunity Program Writing Center at the University of Washington. In J. A. Kinkead \& J. G. Harris (Eds.), Writing centers in context: Twelve case studies. Urbana: NCTE.

Olson, G. A. (Ed.). (1984). Writing centers: Theory and administration. Urbana: NCTE.

Paré, A. \& Smart, G. (1994). Observing genres in action: Towards a research methodology. In A. Freedman \& P. Medway (Eds.), Genre and the new rhetoric. London: Taylor \& Francis.

Scharton, M., \& Neuleib J. (1991). The gift of insight: Personality type, tutoring, and learning. In R.Wallace $\&$ J. Simpson (Eds.), The writing centre: New directions. New York: Garland.

Simard, R. (1984). Assessing a new professional role: The writing center tutor. In G. A. Olson (Ed.), Writing centers: Theory and administration. Urbana: NCTE. 
Simon, L. (1993). The writing center at Harvard University: a studentcentered resource. In J. A. Kinkead \& J. G. Harris (Eds.), Writing centers in context: Twelve case studies. Urbana: NCTE.

Simpson, J. (1991). The role of writing centers in student retention programs. In R. Wallace \& J. Simpson (Eds.), The writing center: New directions. New York: Garland.

Smith, C. M. (1984). Efficiency and insecurity: A case study in form design and records management. In G. A.Olson (Ed.), Writing centers: Theory and administration. Urbana: NCTE.

Wallace, R. (1991). Sharing the benefits and the expense of expansion: Developing a cross-curricular cash flow for a cross-curricular writing center. In R.Wallace \& J. Simpson (Eds.), The writing center: New directions. New York: Garland.

Wallace, R. \& Simpson, J. (Eds.). (1991). The writing center: New directions. New York: Garland.

Warnock, T., \& Warnock, J. (1984). Liberatory writing centers: restoring authority to writers. In G. A. Olson (Ed.), Writing centers: Theory and administration. Urbana: NCTE.

Wolff, W. C. (1991). Writing services: A new role for the writing center and faculty. In R.Wallace \& J. Simpson (Eds.), The writing center: New directions. New York: Garland. 
